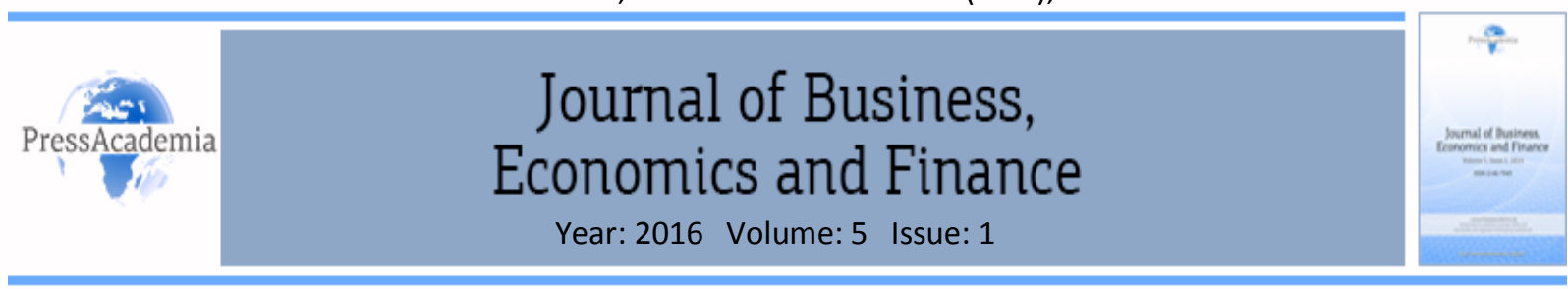

\title{
THE IMPACT OF ENTREPRENEURIAL INTENSITY ON JOB STRESS: THE MEDIATING ROLE OF ROLE AMBIGUITY WITH EVIDENCE FROM TOP 1.000 INDUSTRIAL ORGANIZATIONS OF TURKEY
}

\section{DOI: 10.17261/Pressacademia.2016116550}

\author{
Gultekin Altuntas ${ }^{1}$, Nevzat Demir ${ }^{2}$, Aral Noyan ${ }^{3}$ \\ ${ }^{1}$ Istanbul University. altuntas@istanbul.edu.tr \\ ${ }^{2}$ Firat Plastics and Rubber Industry Inc. n.demir@firat.com \\ ${ }^{3}$ Istanbul Yeniyuzyil University. aral.noyan@gnail.com
}

\begin{abstract}
There are two principal questions were addressed in this study: (a) Does an entrepreneurial intensity (i.e. degree and frequency of entrepreneurial actions inside an organization) contribute to an individual's level of job stress? (b) Does role ambiguity mediate the effect of entrepreneurial intensity on an individual's level of job stress? The data for the study have been taken from the top 1.000 industrial organizations of Turkey as of 2015, a typical example of an emerging economy. The findings reveal that entrepreneurial intensity (both degree and frequency of entrepreneurship) consistently contributes to lower role ambiguity and an individual's level of job stress. It also demonstrates that role ambiguity positively affects an individual's level of job stress and partially mediates the relationship between the frequency of entrepreneurship and his/her level of job stress. Based on the results, some managerial implications for practice and useful suggestions for future research are set forth
\end{abstract}

Keywords: Entrepreneurial intensity, role ambiguity, job stress, industrial organizations, Turkey.

JEL Classification: C91, L26, M12

\section{INTRODUCTION}

Entrepreneurship has been widely associated with and heavily studied with a perspective of the creation of something new or improved (i.e. raw materials, products, services, processes, managerial techniques and technologies or a combination of them) with an allocation of required resources (i.e. of money, time, knowledge, effort, experience) by taking a manageable level of risk (i.e. of financial, social and psychological) to get a reward (i.e. of monetary, personal satisfaction, independence and financial freedom at personal level, value creation for various stakeholders and shareholders at organizational level and economic growth and development at national level) independently for an individual / a group of individuals or within a given organization (Schumpeter, 1934; Hisrich and Peters, 2002; Hamel, 2007; Morris, 1998; Morris, Kuratko an Covin, 2010; Vozikis et al., 1999; Wennekers and Thurik, 1999; Rocha, 2004; Deepti, Shilpa and Kayita, 2015; Foss, Foss and Klein, 2007; Foss et al., 2007; Altuntaş, 2010).

In addition to the use of wealth creation for, entrepreneurship within an organization, which may take various forms and differ significantly compared one to another, is also a need to cope with the constant change in internal and external organizational context, to become more competitive and 'healthy' and even to survive (Morris, Kuratko an Covin, 2010; Allens, 2009; Zahra, 1991; Altuntaş and Dönmez, 2010). With respect to the level of entrepreneurship, an organization can be placed on a continuum ranging from conservative one to entrepreneurial (Covin and Slevin, 1990; Barringer and Ireland, 2008), which involves a radical change in patterns of internal organizational behaviors (Monsen and Boss, 2009). In other words, the level and frequency of entrepreneurial behaviors to determine an organization's point on that continuum, are empirically assessed 
in different industries with the entrepreneurial intensity (EI) construct in (Urban and Sefalafala, 2015). Such an entrepreneurial context in an organization (that individuals inside are expected to be innovative while creating something "new" or 'improved', to take risks of a possible loss and to behave proactively while predicting the change) can be "characterized in periods of relatively high pressure, stress, uncertainty, and ambiguity" (Schindehutte, Morris and Allen, 2006: 349) if "managerial roles are not carefully designed and orchestrated" (Ketchen, Ireland and Snow, 2007).

With this perspective in hand, this paper attempts to analyze the relationship among entrepreneurial intensity, role ambiguity and job stress with required quantitative methods via appropriate statistical tools from an emerging economy perspective after an extensive relevant literature review.

\section{LITERATURE REVIEW}

\subsection{Entreprenurial Intensity}

Entrepreneurial intensity (EI) is defined as the level to what extent both the degree and frequency of entrepreneurship are evidenced within a given organization (Morris and Sexton, 1996; Morris, 1998; Morris and Kuratko, 2002; Morris, Kuratko and Covin, 2010) or the point on which an organization places itself along a continuum ranging from conservative one to entrepreneurial (Covin and Slevin, 1990; Barringer and Ireland, 2008). Whatever definition is made, there is still doubt what is 'entrepreneurial' in an organization and what establishes its underlying nature or where the best place is in that continuum, but the most prominent and researched constructs to describe entrepreneurship are innovativeness, risk-taking and proactiveness (Morris, 1998; Rauch et al. 2009). Although some scholars add 'autonomy' (Lumpkin and Dess, 1996), competitive aggressiveness (Lumpkin and Dess, 1996; Venkatraman, 1989a; 1989b), corporate venturing and self-renewal (Antoncic and Hisrich, 2001) to the constructs in hand, they have not been able get widespread acceptance due to difficulties in terms of operationalization in measurement or viewing some constructs as parts of others (Kraus, 2013; Antoncic and Hisrich, 2003; Scheepers, Hough and Bloom, 2007; Knight, 1997). For the sake of simplicity and making the research consistent with the prior ones, this study employs a view of an entrepreneurial event as the one, which consists a combination of innovativeness, proactiveness and risktaking in line with Morris and Sexton (1996). From this perspective, an entrepreneurial event varies in an organization in terms of the "degree of entrepreneurship", or how much innovativeness, risk-taking, and proactiveness is involved within that event (Kuratko, Hornsby and Goldsby, 2007).

In respect to innovativeness as an organizational mindset (Damanpour, 1991; Kraus, 2013), the degree of entrepreneurship refers to an organization's tendency of the embodiment of new, novel, unique, original and creative ideas, -to produce new or improved raw materials, products, services, processes, managerial techniques and technologies or a combination of them,- which it continuously seeks, engages in, supports and develops through experimentation (Drucker, 1985; Schumpeter, 1934; Covin and Miles, 1999; Stevenson and Gumpert, 1985; Luecke, 2003; Knight, 1987; Sathe, 1989; Dess and Lumpkin, 2005; Neely and Hii, 1991; Mueller and Thomas, 2001; Damanpour, 1991; Kraus, 2013; Chang and Lin, 2011). From this perspective, it is inferred that whatever innovation is made is all about creation, development and application of new ideas and behaviors to unique or improved outputs (Damanpour, 1991; Morris and Kuratko, 2002). Thus, an innovation, which triggers risk-taking and proactive market-leading behaviors (Covin and Slevin, 1991; Khan and Manopichetwattana, 1989), is useful in case it contributes to organizational performance, effectiveness and 'health' and the only sustainable core competence to survival of the organization (Altuntaş, 2010; Koçel, 2005: 314).

With regard to risk-taking, the degree of entrepreneurship is defined as the level of willingness to what extent of an organization allocates its crucial resources which it has and/or controls to the realized large and risky entrepreneurial opportunities in uncertain times with a reasonable chance to costly failure as well as success to get high yield (Miller and Friesen, 1978: 923; Chang and Lin, 2011: 2). Thus, it represents a tendency of an organization to engage resource in high-risk strategies and projects with highly uncertain returns (Wiklund and Shepherd, 2005) or of a manager to take bold or cautious actions to achieve superior performance (Chang and Lin, 2011: 2). Regardless of either an individual or an organization, risk-taking in this sense does not necessarily mean that it is an action without thinking or caring the consequences of return or loss, but rather controlled, 
calculated and managed one as a result of an investment decision or a strategy under uncertainty regarding an initiative, products and services and processes, which an entrepreneur does not perceive as risky (Keh, Foo and Lim, 2002; Covin and Slevin, 1989; 1991; Cornwall and Perlman, 1990; Certo, Moss and Short, 2009). In sum, an organization requires to take 'reasonable' risks as well as to be proactive (Covin and Slevin, 1989), since its riskavoidance with a change in market conditions may result in a loss of sustainable competitive advantage or worse withdrawal from the market in the middle or particularly long-run (Slater and Narver, 1995).

With an aspect of proactiveness as opposed to reactiveness, the degree of entrepreneurship is described as to what extent an organization is knowledgeable about its current customer preferences, can anticipate the change in future demand to identify any possible opportunity and take required actions upon identified opportunities with a 'hands-on' mentality earlier before its competitors to stay ahead of competition particularly with a first-mover advantage (Kraus, 2013; Rauch et al., 2009; Chang and Lin, 2011; Lumpkin and Dess, 1996). As seen, proactiveness is all about a challenging strategy, which an organization follows to take the lead, initiative and risks to seize the opportunities in terms of new products, services, technologies and managerial techniques without falling behind the change in its surrounding environment (Covin and Slevin, 1989; 1991; Bateman and Crant, 1993; Lumpkin and Dess, 1996; Antoncic and Hisrich, 2001; Lee, Lee and Pennings, 2001; Miller, 1987). In this respect, proactiveness requires an organization to develop whatever is necessary to transform an entrepreneurial concept into an innovation with a focus on future such as anticipating problems, demands and changes, developing a plan to take precautions and implementing it perseveringly with taking the responsibility (Kraus, 2013; Lumpkin and Dess, 2001; Chang and Lin, 2011; Morris and Kuratko, 2002).

To better understand $\mathrm{El}$, it is also important to ask the question of how many entrepreneurial (innovative, proactive and risky) events take place within an organization over a given period of time, which is referred as the "frequency of entrepreneurship" in order to produce new products, services and business processes (Kuratko, Morris and Covin, 2011; Morris and Sexton, 1996; Kuratko, Hornsby and Goldsby, 2007; Chang and Lin, 2011; Scheepers, Hough and Bloom, 2007; Erasmus and Scheepers, 2008).

\subsection{Role Ambiguity}

El is influenced by an organization's both external and internal organizational context (Zahra, 1991) since it is embedded in its vision, strategies, objectives, structures and operations (Morris, Kuratko and Covin, 2008) and involves a radical change in patterns of internal organizational behaviors (Monsen and Boss, 2009). With this perspective from top to bottom, entrepreneurial decisions made in an organization require individuals to behave proactively, to be innovative and to take risks since they engage in predicting the "unknown" future, creating something "new" and taking responsibility of a possible "loss", in which high level of pressure, ambiguity cannot be avoided (Teoh and Foo, 1997; Baird and Thomas, 1985; Antoncic and Hisrich, 2003; Lumpkin and Dess, 1996; Chauhan, 2014; Schindehutte, Morris and Allen, 2006: 349). Thus, individuals, in organizations where the need for loose intra-organization boundaries arise (Hornsby et al., 1990; 1993) and there is a high degree and frequency of entrepreneurial events, are expected to perform a number of boundary-spanning tasks, which they are neither trained to do nor expected to have to do (Monsen and Boss, 2009) which requires them to have a high tolerance for ambiguity since they are more likely to engage in creative and novel ways of doing things (Teoh and Foo, 1997). Such an organizational climate that individuals are required to think strategically and act entrepreneurially with a lack of clearly defined tasks and objectives make them feel ill-equipped to handle with the situation or perceive their role to be unclear and ambiguous in other words, which role ambiguity is created (Monsen and Boss, 2009; Demirci, 2013; Upson, Ketchen and Ireland, 2007). With this perspective role ambiguity is often defined as "the degree to which clear information is lacking" about the expectation associated with a role, the method for fulfilling known role expectations and the consequences of role performance (Yongkang et al., 2014). Thus, we propose that

$\mathrm{H} 1$ : The higher the frequency of entrepreneurship, the higher the role ambiguity in an organization.

$\mathrm{H} 2$ : The higher the degree of entrepreneurship, the higher the role ambiguity in an organization. 


\subsection{Job Stress}

In today's world of rapid change and the never-ending flow of information, 'stress' has become a more often topic of discussion and research, due to its results in changes of an individual's daily life in terms of social interaction and level of wellbeing as well as of an organization with a loss in productivity. Stress is defined as being a physical reaction to unexpected and sudden changes and the individual's ability to use the resources available to meet the new challenges in general. In an organizational climate where employees overwork or their roles within the organization are "vague and unclear", or there is a high level of role overload, role conflict and role ambiguity in other words, higher levels of job stress, job-related tension and job dissatisfaction are experienced (Eatough et al., 2011; Kemery et al., 1985; Fogarty, 1996). Combined with role conflict (i.e. employees meet with conflicting goals or demands by managers), role overload and role ambiguity contribute the level of an individual's stress which leads to an increase in compensation claims, absenteeism, reduced productivity, health insurance costs, medical expenses for stress-related illnesses, higher employee turnover (Jimmieson et al., 2004; Fogarty, 1996; Beehr et al., 2000; Savery and Luks, 2000; O'Driscoll and Beehr, 1994; Stoedeur, D'hoore and Vandenberghe, 2001). It is also stated before that "the entrepreneurial context can be characterized in periods of relatively high pressure, stress, uncertainty, and ambiguity" (Schindehutte, Morris and Allen, 2006: 349). Thus, we propose that

H3: The higher the role ambiguity, the higher the job stress in an organization.

H4: The higher the frequency of entrepreneurship, the higher the job stress in an organization.

H5: The higher the degree of entrepreneurship, the higher the job stress in an organization.

\section{METHODOLOGY AND DATA}

\subsection{The Purpose and Model}

As stated before, the purpose of this descriptive study is to analyze the relationship among entrepreneurial intensity, role ambiguity and job stress with required quantitative methods via appropriate statistical tools. Hence the conceptual model proposed in the study is presented in Figure 1.

Figure 1: The Conceptual Model

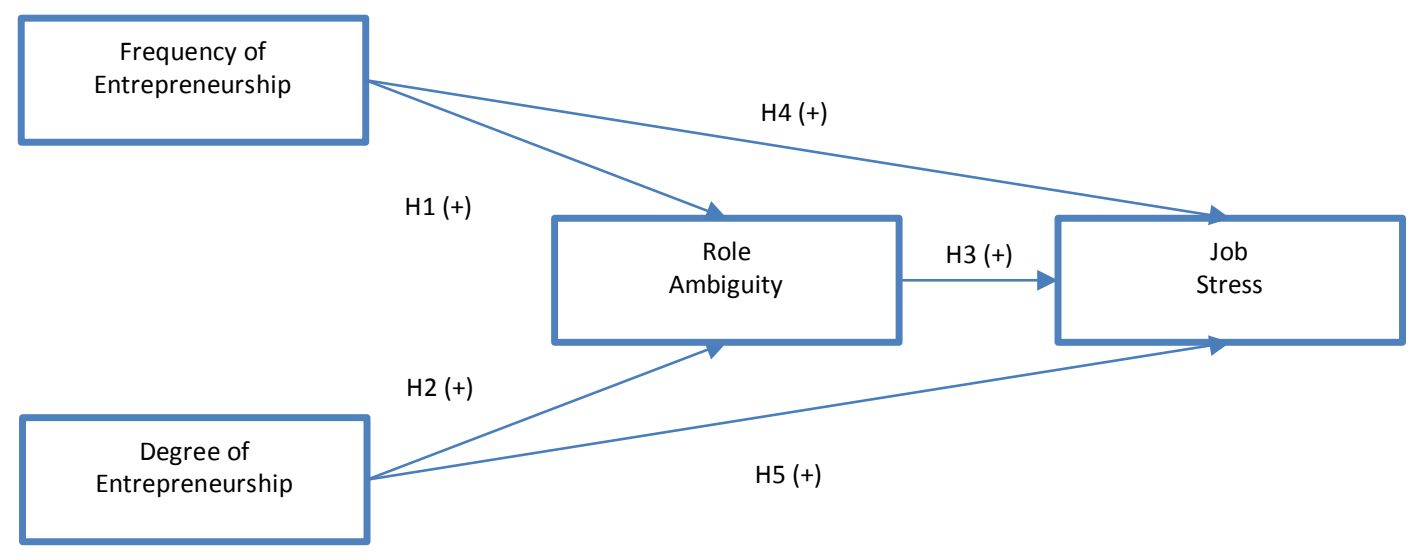

\subsection{The Sample}

To examine the proposed relationships, a research design has been employed with a questionnaire, which was e-mailed to or was filled through a phone conversation by managers of the top 1.000 Industrial Organizations of Turkey, which were announced by Istanbul Chamber of Industry as of June, 2015 without any sampling procedure with a response rate of $45,5 \%$ yielding 455 usable questionnaires in August, 2015. The industrial organizations had been established mainly by domestic capital (78\%), before the year of $1980(65,7 \%)$, with a number of employees more than $250(93,6 \%)$ and a gross sales volume over 20 million USD (49,9\%). The key 
informants were mainly women (56,7\%), aged between $31-40(68,3 \%)$ with a bachelor's degree $(94,7 \%)$, had an experience between $1-5$ years $(47 \%)$ in the organization $1-5$ years $(46,6 \%)$ in the industry.

\subsection{The Scale}

The questionnaire is developed with measures of entrepreneurial intensity (adapted from Covin and Lumpkin (2011); Covin, Green and Slevin (2006) and Kuratko, Morris and Covin (2011)), role ambiguity (adapted from Rizzo, House and Lirtzman (1970)) and job stress (adapted from Kaplanoglu (2014)) with 45 items in total as well as some variables used for classification. Five-point Likert scales are used for all items to measure the constructs based on perceptions of managers to ensure the homogeneity of the instrument.

\subsection{Validity and Reliability}

The measurement items have been translated once from English to Turkish and once from Turkish to English by academics and revised by practitioners to address face and content validity as well as wording flow and clarity. For preliminary tests, an exploratory factor analysis (with a principal components method using a direct oblimin rotation) have been conducted, which leaves several items (with factor loadings below 0.35 ) dropped from the original scales to purify the construct measures (see Table 1). Values for measurement of sampling adequacy in line with $\mathrm{KMO}$ were $0.819,0.500,0.736,0.789$ respectively within the permissible thresholds and all were significant in accordance with Bartlett's Test of Sphericity.

Table 1: Measurement Model of Constructs

\begin{tabular}{|c|c|c|c|c|}
\hline Constructs & \multicolumn{2}{|c|}{ Factor Loadings* } & & \multirow[t]{2}{*}{ Cronbach's Alpha } \\
\hline Frequency of Entrepreneurship (in last two years) $* *$ (Total Variance Explained $=78,533 \%$ ) & & & & \\
\hline Frequency of product improvements or developments. & 0.91 & & & \\
\hline Frequency of new product introductions completely new to the market. & 0.89 & & & \\
\hline Frequency of new service introductions compared to major competitors. & 0.89 & & & \\
\hline Frequency of new service introductions completely new to the market. & 0.87 & & & \\
\hline Frequency of significantly revised or improved services. & 0.87 & & & \\
\hline Frequency of new product introductions compared to major competitors. & 0.86 & & & \\
\hline Degree of Entrepreneurship ** (Total Variance Explained = 54,929\%) & & & & $* * *$ \\
\hline We offer more new product/services to the market compared to competitors. & & 0.74 & & \\
\hline We continuously improve our methods/processes of production and services. & & 0.74 & & \\
\hline Role Ambiguity** (Total Variance Explained $=88,331 \%$ ) & & & & $\alpha=0.94$ \\
\hline I know that I have divided my time properly. & & 0.95 & & \\
\hline I feel certain about how much authority I have. & & 0.94 & & \\
\hline I know exactly what is expected of me. & & 0.89 & & \\
\hline Job Stress $* *$ (Total Variance Explained $=55,116 \%)$ & & & & $\alpha=0.88$ \\
\hline My job tension gets me slim. & & & 0.83 & \\
\hline I work under pressure. & & & 0.81 & \\
\hline I am frequently asking myself if it is worth this much effort. & & & 0.76 & \\
\hline My job directly affects my health. & & & 0.76 & \\
\hline I feel tense as a result of my job. & & & 0.75 & \\
\hline I have to think about too many things at once. & & & 0.69 & \\
\hline I am still thinking of my work before falling asleep. & & & 0.68 & \\
\hline I feel anxious about the decision I make even if it is true. & & & 0.65 & \\
\hline
\end{tabular}

\footnotetext{
* Item loadings below 0.35 have been discarded.

** KMO values for sampling adequacy of each construct were in permissible thresholds ranging from 0.500 to 0.819 and were significant in accordance with Bartlett's Test of Sphericity at 0.05 level.

*** When a scale is composed of two items, there is still doubt about which reliability statistics (of Cronbach's Alpha Coefficient, Pearson Correlation Coefficient or Spearman-Brown's Formula) is an appropriate measure to report (Please see Eisinga, te Grotenhuis and Pelzer (2013) for details). Although Cronbach's Alpha Coefficient is below widely accepted limit of 0.60 , these two-items are significantly correlated at 0.05 significance level. Thus, the scale composed of this two-items is regarded as 'reliable'.
} 


\subsection{Descriptive Results}

Construct means, standard deviations, and correlations are presented in Table 2. The scores on each of the four constructs are normally distributed. Participants perceive the level of entrepreneurial intensity within their organizations to be moderately high in respect to frequency (Mean $=3.96$; Std. Dev. $=0.92$ ) and degree (Mean $=4.45$; Std. Dev. $=0.40$ ) of entrepreneurship with averages over the midpoint of the scale. Overall, participants report highly low levels of role ambiguity (Mean $=1.50$; Std. Dev. $=0.60$ ) and job stress (Mean = 1.85; Std. Dev. $=0.63)$.

The largest correlation coefficient among independent variables appeared as -0.23 . Frequency entrepreneurship has a weak and positive relationship with degree of entrepreneurship $(r=0.11 ; p<0.05)$; $a$ weak and negative relationship with role ambiguity $(r=-0.22 ; p<0.01)$ and job stress $(0.23 ; p<0.01)$. In addition, degree of entrepreneurship is in weak and negative relationships with role ambiguity $(r=-0.12 ; p<$ $0.01)$ and job stress $(r=-0.14 ; p<0.01)$ respectively. However, role ambiguity is weakly and positively related to job stress $(r=0.20 ; p<0.01)$.

\section{Table 2: Descriptive Statistics and ilnter-Construct Correlations}

\begin{tabular}{|l|l|c|c|c|c|c|c|}
\hline \multicolumn{2}{|l|}{ Constructs } & Mean & Std. Dev. & $\mathbf{1}$ & $\mathbf{2}$ & $\mathbf{3}$ & $\mathbf{4}$ \\
\hline 1 & Frequency of Entrepreneurship & 3.96 & 0.92 & 1.00 & & & \\
\hline 2 & Degree of Entrepreneurship & 4.45 & 0.40 & $0.11^{*}$ & 1.00 & & \\
\hline 3 & Role Ambiguity & 1.50 & 0.60 & $-0.22^{* *}$ & $-0.12^{*}$ & 1.00 & \\
\hline 4 & Job Stress & 1.85 & 0.63 & $-0.23^{* *}$ & $-0.14^{* *}$ & $0.20^{* *}$ & 1.00 \\
\hline
\end{tabular}

* Correlation is significant at the 0.05 level (2-tailed).

** Correlation is significant at the 0.01 level (2-tailed).

\subsection{Effect Estimates}

Only unstandardized effects of coefficients in the final 'saturated' model are discussed here (Figure 2 and Table $3)$. All path coefficients in the model are statistically significant $(p<0.05)$ and some of which are not in the hypothesized directions.

Figure 2: Structural Path Estimations

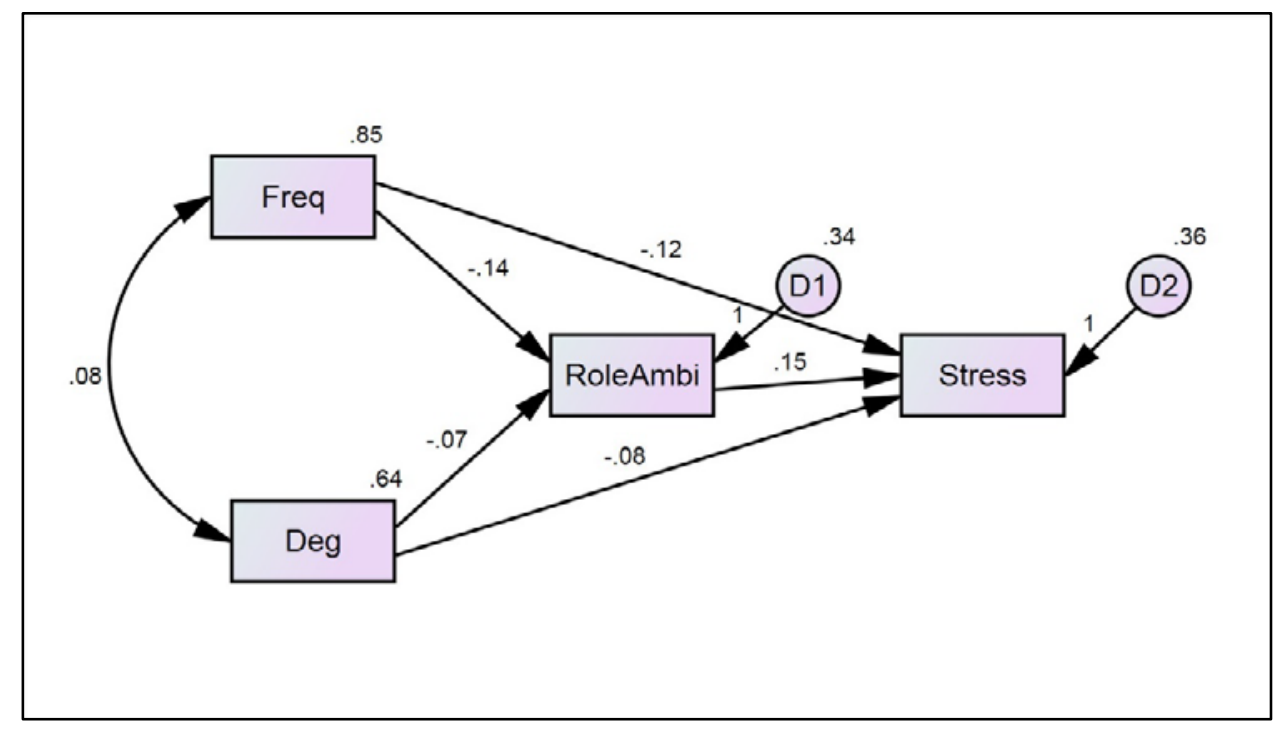


Frequency of entrepreneurship is found to exert a weak and negative direct impact on job stress $(b=-0.12 ; p<$ $0.05)$ and a weak and negative direct impact on role ambiguity $(b=-0.14 ; p<0.05)$, which in turn has a weak and positive direct impact on job stress $(b=0.15 ; p<0.05)$. In addition, degree of entrepreneurship is reasoned to reflect weak and negative direct impacts on both role ambiguity $(b=-0.07 ; p<0.05)$ and job stress $(b=-$ $0.14 ; p<0.08)$. Frequency of entrepreneurship has also an indirect effect on job stress $(b=-0.02 ; p<0.05)$ does as degree of entrepreneurship on job stress $(b=-0.11 ; p<0.05)$. Sobel test confirms that role ambiguity statistically significant has a partial mediation effect on the relationship between frequency of entrepreneurship and job stress $(p<0.01)$. However, Sobel test disclaims that there is any mediation effect of role ambiguity on the relationship between degree of entrepreneurship and job stress $(p=0.11)$.

Table 3: Structural Path Estimations

\begin{tabular}{|c|c|c|c|c|c|}
\hline \multicolumn{2}{|c|}{ Structural Paths } & $\mathbf{H}_{0}$ & Result & Coefficient & Sig. \\
\hline \multicolumn{6}{|l|}{ Direct Effects } \\
\hline of & on & & & & \\
\hline Frequency of Entrepreneurship & Role Ambiguity & $\mathrm{H}_{1}$ & Not Supported & $-0,14$ & $*$ \\
\hline Degree of Entrepreneurship & Role Ambiguity & $\mathrm{H}_{2}$ & Not Supported & $-0,07$ & $*$ \\
\hline Role Ambiguity & Job Stress & $\mathrm{H}_{3}$ & Supported & 0,15 & * \\
\hline Frequency of Entrepreneurship & Job Stress & $\mathrm{H}_{4}$ & Not Supported & $-0,12$ & * \\
\hline Degree of Entrepreneurship & Job Stress & $\mathrm{H}_{5}$ & Not Supported & $-0,08$ & * \\
\hline \multicolumn{6}{|l|}{ Indirect Effects (through Role Ambiguity) } \\
\hline of & on & & & & \\
\hline Frequency of Entrepreneurship & Job Stress & $\mathrm{H}_{6}$ & Not Supported** & -0.02 & * \\
\hline Degree of Entrepreneurship & Job Stress & $\mathrm{H}_{7}$ & Not Supported & -0.11 & Not Sig. \\
\hline
\end{tabular}

\section{DISCUSSION AND IMPLICATIONS}

Based on extant literature of entrepreneurship, organizational behavior and human resources management, it is examined that direct and indirect effects of entrepreneurial intensity on role ambiguity and job stress in a scope of the top 1.000 industrial organizations of Turkey in this study. Having been developed a conceptual model, it was tested with a use of 455 usable questionnaires in August, 2015. Findings suggest that frequency and degree of entrepreneurship is negatively related to role ambiguity and job stress in contrary to our hypothesis and prior work of Schindehutte, Morris and Allen (2006) although role ambiguity and job stress are positively correlated to each other as expected. Individuals in entrepreneurial organizations are expected to bear greater uncertainty, to cope with transformational and high frequency change, to handle with loose and ever shifting boundaries among different units, decide quickly among multiple competing alternatives with insufficient information (Hayton, 2005: 24; Rafferty and Griffin, 2006; Buttner, 1992). Thus, what might be the case of a negative relationship between entrepreneurial intensity and role ambiguity? Individuals might learn how to overcome associated with disruptive innovations and new business models (Ireland, Hitt and Sirmon, 2003), have developed a better self-efficacy traits (Rutherford and Holt, 2007) and/or experienced the need for on-going adaption process to change before (Schindehutte and Morris, 2001) or be working under the positive impact of entrepreneurial managers (Pearce, Kramer and Robbins, 1997) in an organization with a culture supporting change and creativity (Upson, Ketchen and Ireland, 2007), all of which decrease role ambiguity. It is also known that numerous and 'tangled' communication channels inside an entrepreneurial organization, which resembles a bowl of spaghetti (Cornwall and Perlman, 1990) are the key to organizational change (Clarke, 1994). "The more, the better" approach in terms of communication might be helping individuals overcome their fears of entrepreneurship since "open routine communication practices are positively related to corporate entrepreneurship" (Agnieszka and Agnieszka, 2015). Furthermore, since the population is the top 1.000 industrial organizations of Turkey, it is expected to follow some kind of formalization and centralization processes which reduce role ambiguity (Organ and Greene, 1991; Caruana, Morris and Vella, 1998) although they inhibit entrepreneurial intensity inside the organization if not balanced. 
In addition, it might be the case (a study limitation in fact) that individuals' risk aversion behaviors are to be transformed into an organizational-level or they work at different levels of hierarchy, which needs them perform distinct behaviors (Monsen and Boss, 2009).

When it comes to the relationship between entrepreneurial intensity and job stress, it is expected for individuals in an entrepreneurial context to have a relatively high level of stress (Schindehutte, Morris and Allen, 2006: 349). Furthermore, entrepreneurs were found to have higher level of stress associated with workload compared to white collar, blue collar and professional groups (Harris, Saltstone and Fraboni, 1999). Thus, what might be the case of a negative relationship between entrepreneurial intensity and job stress? It might be due to the interaction among the variables of entrepreneurship, job satisfaction, affective commitment and job stress. As stated in person-organization fit studies before, a closer match between the individual and the organizational environment will result in a higher level of job satisfaction and affective commitment, which leads to a higher level of motivation and organizational performance as in entrepreneurial start-ups (Markman and Baron, 2003; Rutherford and Holt, 2007; Rutherford, Holt and Clohessy, 2009). Furthermore, the level of job satisfaction might increase due to a formal training on entrepreneurship (Hindle and Cutting, 2002). Thus, due to a negative correlation between either job satisfaction or affective commitment and job stress (Kuo, 2015), we might find that entrepreneurial intensity is in a negative relationship with job stress.

Based on the findings of this study, we may suggest some managerial implications. First of all, it seems that an entrepreneurial context is likely to create some 'soft' favorable outcomes such as a lower level of role ambiguity and job stress. As opposed to prior expectations we had in the literature review section, entrepreneurial intensity seems to creating or even lowering the level of 'role ambiguity' (Monsen and Boss, 2009). Regardless of size, age or industry, if managerial roles are 'carefully' designed and orchestrated or when individuals have gradually higher levels of tolerance for ambiguity to cope with an ongoing change in the environment, we expect a lower level of role ambiguity in an entrepreneurial organization. It also appears that managers should create an entrepreneurial climate (by taking into consideration a balance between the degree and frequency of entrepreneurial actions) to decrease the level of job stress among employees.

Based on the earlier findings and discussions in this study, we makes several suggestions for future research. Although this study reports some enlightening results to promote a better understanding of the relationships among entrepreneurial intensity, role ambiguity and job stress, it needs to be explored more using qualitative and quantitative studies regarding those variables observed. In addition, information on personality type and previous experience in an entrepreneurial organization should be collected and used as a moderator on the relationships among entrepreneurial intensity, role ambiguity and job stress. It is also important for the variables of job satisfaction and affective commitment to be included in such a study, which we believe have some potential intervening effects on entrepreneurial intensity, role ambiguity and job stress.

\section{REFERENCES}

Agnieszka, Z. \& Agnieszka, W. 2015, "Routines do matter: role of internal communication in firm-level entrepreneurship," Baltic Journal of Management, vol. 10, no. 1, pp.119-139.

Allens, R. K. 2009, “Launching new ventures: An entrepreneurial approach,” Houghton Mifflin Company Boston New York.

Altuntaş, G. 2010, "The relationship between entrepreneurship and strategic management: A new model and test of strategic entrepreneurship," Unpublished dissertation. Istanbul University, the Institute of Social Sciences.

Altuntaş, G. \& Dönmez, D. 2010, "The relationship between entrepreneurial orientation and organizational performance: Evidence from the hotel industry in Çanakkale Region," Journal of Journal of the School of Business Administration, Istanbul University, vol. 40, no. 2, pp. 278-303.

Antoncic, B. \& Hisrich, R. D. 2001, "Intrapreneurship: Construct refinement and cross-cultural validation," Journal of Business Venturing, vol. 16 , no. 5 , pp. $495-527$.

Antoncic, B. \& Hisrich, R. D. 2003, "Clarifying the intrapreneurship concept," Journal of Small Business and Enterprise Development, vol. 10, no. 1 , pp. 7-24. 
Baird, I. S. \& Thomas, H. 1985, "Toward a contingency model of strategic risk taking," Academy of Management Review, vol. 10, no. 2, pp. 230-243.

Barringer, B. C. \& Ireland, R. D. 2008, “Entrepreneurship: Successfully launching new ventures," $2^{\text {nd }}$ Edition, Upper Saddle River, NJ: Pearson/Prentice-Hall.

Bateman, T. S. \& Crant, J. M. 1993, "The proactive component of organizational behavior: A measure and correlates," Journal of Organizational Behavior, vol. 14, no. 2, pp. 103-118.

Beehr, T. A., Jex, S. M., Stacy, B. A. \& Murray, M. A. 2000, “Work stressors and co-worker support as predictors of individual strain and job performance," Journal of Organizational Behavior, vol. 21, pp. 392-403.

Buttner, E. H. 1992, “Entrepreneurial stress: Is it hazardous to your health?," Journal of Managerial Issues, vol. 4, no. 2, pp. $223-240$.

Caruna, A. Morris, M. H. \& Vella, A. J. 1998, "The effect of centralization and formalization on entrepreneurship in export firms," Journal of Small Business Management, January, pp. 16-29.

Certo, S. T., Moss, T. W. \& Short, J. C. 2009, "Entrepreneurial orientation: An applied perspective," Business Horizons, vol. 52, no. 4, pp. 319-324.

Chang. H. J. \& Lin, S. J. 2011, "Entrepreneurial intensity in catering industry: A case study on Wang Group in Taiwan," Business and Management Review, vol. 1, no. 9, pp. 1-12.

Chauhan, A. P. 2014, "Organizational role stress," International Journal of Advanced Research in Management and Social Science, vol. 3, no. 2, pp. 154-171.

Clarke, L. 1994, “The essence of change," London: Prentice Hall International.

Cornwall, J. R. \& PerIman, B. 1990, “Organizational entrepreneurship,” Homewood, IL: Boston-Irvin.

Covin, J. G. \& Lumpkin, G. T. 2011, “Entrepreneurial orientation theory and research: Reflections on a needed construct," Entrepreneurship Theory and Practice, vol. 35, no. 5, pp. 855-872.

Covin, J. G. \& Miles, M. P. 1999, "Corporate entrepreneurship and the pursuit of competitive advantage," Entrepreneurship Theory and Practice, vol. 23, no. 3, pp. 47-63.

Covin, J. G. \& Slevin, D. P. 1989, "Strategic management of small firms in hostile and benign environment," Strategic Management Journal, vol. 10, no. 1, pp. 75-87.

Covin, J. G. \& Slevin, D. P. 1990, "New venture strategic posture, structure and performance: An industry life cycle analysis," Journal of Business Venturing, vol. 5, pp. $123-135$.

Covin, J. G. \& Slevin, D. P. 1991, “A conceptual model of entrepreneurship as firm behavior," Entrepreneurship Theory and Practice, vol. 16, no. 1 , pp. 7-24.

Covin, J. G., Green, K. \& Slevin, D. P. 2006, "Strategic process effects on the entrepreneurial orientation - sales growth rate relationship," Entrepreneurship Theory and Practice, vol. 30, no. 1, pp. 57-81.

Damanpour, F. 1991, "Organizational innovation: A meta-analysis of effects of determinants and moderators," The Academy of Management Journal, vol. 34, no. 3, pp. 555-590.

Deepti P., Shilpa, J. \& Kavita, C. 2015, “Entrepreneurial intensity in relation to presence of entrepreneurship development cell: A study of institutes offering professional courses in national capital region Delhi, India," The International Journal of Management Education, vol. 13, no. 1 , pp. 95-105.

Demirci, A. 2013, "Cross-cultural differences in entrepreneurial tendencies: An exploratory view in Turkey and Canada". International Journal of Entrepreneurship, vol. 17, pp. 21-40.

Dess, G. G. \& Lumpkin, G. T. 2005, "The role of entrepreneurial orientation in stimulating effective corporate entrepreneurship," Academy of Management Executive, vol. 19, no. 1, pp. 147-156.

Drucker, P. 1985, "The discipline of the innovator," Harvard Business Review, vol. 63, no. 3, pp. 67-72.

Eatough, E. M., Chang, C. H., Miloslavic, S. A. \& Johnson, R. E. 2011, "Relationships of role stressors with organizational citizenship behaviour: A meta-analysis," Journal of Applied Psychology, vol. 96, pp. 620-621.

Eisinga, R., te Grotenhuis, M. \& Pelzer, B. 2013, "The reliability of a two-item scale: Pearson, Cronbach, or Spearman-Brown?," International Journal of Public Health, vol. 58, pp. 637-642.

Erasmus P. \& R. Scheepers, 2008, "The relationship between entrepreneurial intensity and shareholder value creation," Managing Global Transitions, vol. 6, no. 3, pp. 229-56.

Fogarty, T. J. 1996, "An examination of job tension and coping in the relationship between stressors and outcomes in public accounting," Journal of Managerial Issues, vol. 8, no. 3, pp. 269-285. 
Hamel, G. 2007, "The future of management," Boston, MA: Harvard Business School Press.

Harris, J. A, Saltstone, R. \& Fraboni, M. 1999, “An evaluation of the job stress questionnaire with a sample of entrepreneurs," Journal of Business and Psychology, vol. 13, no. 3, pp. 447-455.

Hayton, J. C. 2005, "Promoting corporate entrepreneurship through human resource management practices: A review of empirical research," Human Resources Management Review, vol. 15, no. 1, pp: 21-41.

Hindle, K. \& Cutting, N. 2002, "Can applied entrepreneurship education enhance job satisfaction and financial performance? An empirical investigation in the Australian pharmacy profession," Journal of Small Business Management, vol. 40, no. 2, pp. 162-167.

Hisrich, D. R. \& Peters, P. M. 2002, “Entrepreneurship,” London, UK: McGraw-Hill Irwin.

Hornsby, J. S., Naffziger, D. W., Kuratko, D. F. \& Montagno, R. V. 1990, “Developing an intrapreneurial assessment instrument for an effective corporate entrepreneurial environment," Strategic Management Journal, vol. 11, pp. 49-58.

Hornsby, J. S., Naffziger, D. W., Kuratko, D. F. \& Montagno, R. V. 1993, “An interactive model of the corporate entrepreneurship process," Entrepreneurship Theory and Practice, vol. 17, no. 2, pp. 29-37.

Jimmieson, N. L., Terry, D. J. \& Callan, V. J. 2004, "A longitudinal study of employee adaptation to organizational change: the role change related information and change-related self-efficacy," Journal of Occupational Health Psychology, vol. 9, no. 1, pp. 11-27.

Kaplanoglu, E. 2014, "The basic causes and potential consequences of occupational stress: A study of certified public accountants in Manisa Province," Journal of Accounting and Finance, October, pp. 131-150.

Keh, H. T., Foo, M. D. \& Lim, B. C. 2002, “Opportunity evaluation under risky conditions: The cognitive processes of entrepreneurs," Entrepreneurship Theory and Practice, vol. 27, no. 2, pp. 125-148.

Kemery, E. R., Bedeian, A. G., Mossholder, K. W. \& Touliatos, J. 1985, "Outcomes of role stress: a multi-sample constructive replication," Academy of Management Journal, vol. 28, no. 2, pp. 363-375.

Ketchen, D. J., Jr., Ireland, R. D. \& Snow, C. C. 2007, "Strategic entrepreneurship, collaborative innovation, and wealth creation," Strategic Entrepreneurship Journal, vol. 1, no. 3-4, pp. 371-385.

Khan, A. M. \& Manopichetwattana, V. 1989, “Models for innovative and non-innovative small firms," Journal of Business Venturing, vol. 4, no. 3, pp. 187-196.

Knight, G. 1997, "Cross-cultural reliability and validity of a scale to measure firm entrepreneurial orientation," Journal of Business Venturing, vol. 12, no. 3, pp. 213-225.

Koçel, T. 2005, “Business management," $10^{\text {th }}$ Edition, Istanbul, Turkey: Arıkan Basım Yayım Dağıtım Ltd. Şti.

Kraus, S. 2013, "The role of entrepreneurial orientation in service firms: empirical evidence from Austria," The Service Industries Journal, vol. 33, no. 5, pp. 427-444.

Kuo, S. Y. 2015, "Occupational stress, job satisfaction, and affective commitment to policing among Taiwanese police officers," Police Quarterly, vol. 18, no. 1, pp. 27-54, DOI: 10.1177/1098611114559039

Kuratko, D. F., Hornsby, J. S. \& Goldsby, M. G. 2007, "The relationship of stakeholder salience, organizational posture, and entrepreneurial intensity to corporate entrepreneurship," Journal of Leadership and Organizational Studies, vol. 13, no. 4, pp. 56-72.

Kuratko, D. F., Morris, M. H. \& Covin, J. G. 2011, “Corporate innovation and entrepreneurship,” $3^{\text {rd }}$ Edition, Canada: Cengage Learning.

Lee, C., Lee, K. \& Pennings, J. M. 2001, "Internal capabilities, external networks, and performance: A study of technology-based ventures," Strategic Management Journal, vol. 22, no. 6-7, pp. 615-640.

Luecke, R. 2003, “Managing creativity and innovation," Boston, MA: Harvard Business Essentials.

Lumpkin, G. T. \& Dess, G. G. 1996, "Clarifying the entrepreneurial orientation construct and linking it to performance," Academy of Management Executive, vol. 21, no. 3, pp. 135-172.

Lumpkin, G. T. \& Dess, G. G. 2001, "Linking two dimensions of entrepreneurial orientation to firm performance: The moderating role of environment and industry life cycle," Journal of Business Venturing, vol. 16, no. 5, pp. 429-451.

Markman, G. D. \& Baron, R. A. 2003, "Person-entrepreneurship fit: Why some people are more successful as entrepreneurs than others," Human Resource Management Review, vol. 13, no. 2, pp. 281-301.

Miller, D. 1987, "Strategy making and structure: Analysis and implication for performance," Academy of Management Journal, vol. 30, no. 1, pp. 7-32.

Miller, D. \& Friesen, P. 1978, “Archetypes of strategy formulation,” Management Science, vol. 24, pp. 921-933.

Monsen, E. \& Boss, R. W. 2009, "The impact of strategic entrepreneurship inside the organization: Examining job stress and employee retention," Entrepreneurship Theory and Practice, vol. 33, no. 1, pp. 71-104. 
Morris, M. H. 1998, "Entrepreneurship intensity: Sustainable advantages for individuals, organizations and societies," London: Quorum Books.

Morris, M. H., \& Kuratko, D. F. 2002, “Corporate entrepreneurship: Entrepreneurial development within organizations," London: Thompson South Western.

Morris, M. H. \& Sexton, D. L. 1996, "The concept of entrepreneurial intensity: Implications for company performance," Journal of Business Research, vol. 36, no. 1 , pp. 5-13.

Morris, M. H., Kuratko, D. F. \& Covin, J. G. 2010, “Corporate entrepreneurship and innovation," Mason: Thompson/South-Western Publishing.

Mueller, S. \& Thomas, A. 2001, "Culture and entrepreneurial potential: A nine country study of locus of control and innovativeness," Journal of Business Venturing, vol. 16, no. 1, pp. 51-75.

Neely, A. \& Hii, J. 1998, “Innovation and business performance: A literature review," Cambridge, MA: The Judge Institute of Management Studies.

O'Driscoll, M. P. \& Beehr, T. A. 1994, "Supervisor behaviors, role stressors and uncertainty as predictors of personal outcomes for subordinates," Journal of Organizational Behavior, vol. 15, pp. 143-154.

Organ, D. W. \& Greene, C. N. 1981, "The effects of formalization on professional involvement: A compensatory process approach," Administrative Science Quarterly, vol. 26, no. 2, pp. 237-252.

Pearce, J. A., II, Kramer, T. R. \& Robbins, D. K. 1997, “Effects of managers' entrepreneurial behaviour on subordinates," Journal of Business Venturing, vol. 12, no. 2, pp. 147-160.

Rafferty, A. E. \& Griffin, M. A. 2006, "Perceptions of organizational change: A stress and coping perspective," Journal of Applied Psychology, vol. 91, no. 5, pp. 1154-1162.

Rausch A., Wiklund, J., Lumpkin, G. T. \& Frese, M. 2009, “Entrepreneurial orientation and business performance: An assessment of past research and suggestions for future," Entrepreneurship Theory and Practice, vol. 33, no. 3, pp. 761-787.

Rizzo, J. R., House, R. J. \& Lirtzman, S. I. 1970, "Role conflict and ambiguity in complex organizations," Administrative Science Quarterly, vol. 15, no. 2 , pp. $150-163$.

Rocha, H. 2004, “Entrepreneurship and development: The role of clusters," Small Business Economics, vol. 23, no. 5, pp. 363-400.

Rutherford, M. W. \& Holt, D. T. 2007, "Corporate entrepreneurship: An empirical look at the innovativeness dimension and its antecedents," Journal of Organizational Change Management, vol. 20, no. 3, pp. 429-446.

Rutherford, M. W., Holt, D. T. \& Clohessy, G. R. 2007, “Corporate entrepreneurship: An empirical look at individual characteristics, context, and process," Journal of Leadership and Organizational Studies, vol. 13, no. 4, pp. 40-54.

Sathe, V. 1989, "Fostering entrepreneurship in a large diversified firm,” Organizational Dynamics, vol. 18, no. 1, pp. 20-32.

Savery, L. K. \& Luks, J. A. 2000, “Long hours at work: Are they dangerous and do people consent to them?," Leadership and Organizational Development Journal, vol. 21, no. 6, pp. 307-310.

Scheepers, M. J., Hough, J. \& Bloom, J. Z. 2008, "Nurturing the corporate entrepreneurship capability," South African Business Review, vol. 12 , no. 3 , pp. 50-75.

Schindehutte, M. \& Morris, M. H. 2001, “Understanding strategic adaptation in small firms," International Journal of Entrepreneurial Behaviour and Research, vol. 7, no. 3, pp. 84-107.

Schindehutte, M., Morris, M. H. \& Allen, J. 2006, "Beyond achievement: Entrepreneurship as extreme experience," Small Business Economics, vol. 27, no. 4, pp. 49-68.

Schumpeter, J. A. 1934, "The theory of economic development," Boston, MA: Harvard University Press.

Slater, S. F. \& Narver, J. C. 1995, “Market orientation and the learning organization," Journal of Marketing, vol. 59, July, pp. 63-74.

Stevenson, H. H. \& Gumpert, D. E. 1985, “The heart of entrepreneurship,” Harvard Business Review, March-April, pp. 85-94.

Stoedeur, S., D'hoore, W. \& Vandenberghe, C. 2001, "Leadership, organizational stress, and emotional exhaustion among hospital nursing staff," Journal of Advanced Nursing, vol. 35, pp. 534-535.

Teoh, H. Y. \& Foo, S. L. 1997, "Moderating effects of tolerance for ambiguity and risk taking propensity on the role conflict-perceived performance relationship: Evidence from Singaporean entrepreneurs," Journal of Business Venturing, vol. 12, pp. 67-81.

Upson, J. W., Ketchen, D. J. \& Ireland, R. D. 2007, "Managing employee stress: a key to the effectiveness of strategic supply chain management," Organizational Dynamics, vol. 36, pp. 78-92.

Urban, B. \& Sefalafala, M. R. 2015, "The influence of entrepreneurial intensity and capabilities on internationalisation and firm performance," South African Journal of Economic and Management Sciences, vol. 18, no. 2, pp. 260-276. 
Venkatraman, N. 1989a, "The concept of fit in strategy research: Toward verbal and statistical correspondence," The Academy of Management Review, vol. 14, no. 3, pp. 423-444.

Venkatraman, N. 1989b, "Strategic orientation of business enterprises: The construct, dimensionality, and measurement," Management Science, vol. 35, no. 8, pp. 942-962.

Vozikis, G. S., Bruton, G. D., Prasad, D. \& Merikas, A. A. 1999, "Linking corporate entrepreneurship to financial theory through additional value creation," Entrepreneurship Theory and Practice, vol. 24, no. 2, pp. 33-43.

Wennekers, S. \& Thurik, R. 1999, “Linking entrepreneurship to economic growth,” Small Business Economics, vol. 13, no. 1, pp. 27-55.

Wiklund, J. \& Shepherd, D. 2005, "Entrepreneurial orientation and small business performance: A configurational approach," Journal of Business Venturing, vol. 20, no. 1, pp. 71-91.

Yongkang, Z., Weixi, Z, Yalin, H., Yipeng, X. \& Liu, T. 2014, "The relationship among role conflict, role ambiguity, role overload and job stress of Chinese middle-level cadres," Chinese Studies, vol. 3, no. 1, pp. 8-11.

Zahra, S. A. 1991, "Predictors and financial outcomes of corporate entrepreneurship: An exploratory study," Journal of Business Venturing, vol. 6, no. 4, pp. 259-285. 